\title{
Tingkat Ketahanan Kawasan Informal Terhadap Dampak Perubahan Iklim di Pesisir Kota Bandar Lampung
}

\author{
Warid Zul Ilmi ${ }^{1}$, Adnin Musadri Asbi ${ }^{1}$, dan Tamaluddin Syam ${ }^{2}$ \\ ${ }^{1}$ Institut Teknologi Sumatera, ${ }^{2}$ Universitas Lampung \\ e-mail:waridzulilmi@yahoo.com
}

\begin{abstract}
Abstrak - Kawasan informal di pesisir Kota Bandar Lampung memiliki resiko tinggi terhadap perubahan iklim sehingga perlu adanya riset mengenai ketahaan kawasan informal terhadap dampak perubahan iklim yang terjadi. Metode pengumpulan data penelitian ini menggunakan questionnaire-based interview. Metode analisis data terdiri dari scoring dan pembobotan serta penentuan dimensi prioritas dengan metode analisis kuadran utama. Pada penelitian ini didapatkan bahwa terdapat 8 dimensi ketahanan yang tergolong rendah $(0-40 \%)$ dan 1 dimensi ketahanan tergolong sedang $(41-60 \%)$, dengan tingkat ketahanan dari yang paling rendah berdasarkan pembagian tiga daerah studi kawasan informal di Kelurahan Kota Karang dan Kelurahan Kangkung. Secara keseluruhan, tingkat ketahanan kawasan informal berada di tingkat ketahanan rendah (0-40\%) dengan persentase ketahanan $27,7 \%$. Peningkatan ketahanan dapat dilakukan dengan intervensi pada dimensi-dimensi kuadran I dan III yaitu infrastruktur dan lingkungan alam (infrastruktur bencana), pengetahuan risiko (pelatihan dan sosialisasi), peringatan dini dan evakuasi (rencana dan prosedur evakuasi), tanggap darurat (simulasi), dan manajemen sumber daya pesisir (pengelolaan sumber daya pesisir, konservasi mangrove, dan perilaku hidup bersih dan sehat).
\end{abstract}

Kata Kunci-Dampak Perubahan Iklim, Kawasan Informal, Ketahanan

\section{PENDAHULUAN}

$\mathrm{D}$ iprediksi bahwa da tahun 2030 diprediksi akan ada sekitar $61 \%$ penduduk dunia yang bermukim di perkotaan. Sehingga akan memicu terpusatnya permukiman ilegal dan informal di sekitar perkotaan. [1]. Terdapat sekitar $70 \%$ masyarakat dari pemukiman kampung pada tahun 2010 [2]. Dengan kata lain fenomena informal ikut memiliki peran krusial dalam eksistensi kota di Indonesia sekaligus memberi peringatan bahwa akan terjadi peningkatan jumlah masyarakat rentan terhadap bencana alam, konflik sipil, dan dampak dari perubahan iklim [1]. Selain itu, fenomena ini juga memberikan kesan buruk pada wajah kota sehingga banyak kebijakan yang diambil cenderung kaku dan terburu-buru, seperti melakukan relokasi/penggusuran dan pembangunan yang seringkali menggeser masyarakat yang hidup di permukiman informal.

Penduduk Kota Bandar Lampung pun memiliki ciri-ciri yang sama. Masyarakat membangun tempat tinggal di atas tanah lahan reklamasi pantai yang terjadi penambahan daratan karena kondisi tertentu. Kebanyakan di antara mereka tidak mempunyai bukti yang sah dalam kepemilikan tanah berdasarkan hukum. Situasi tersebut dapat menjadi permasalahan yang tidak bisa dianggap remeh karena akan berdampak pada perubahan iklim [3]. Kelurahan Kangkung dan Kota Karang merupakan wilayah di pesisir Kota Bandar Lampung yang memiliki karakteristik dekat dengan pusat kegiatan perdagangan dan jasa yang mendorong banyak warga juga bertempat tinggal di sana. Kawasan ini dikategorikan sebagai permukiman kumuh dan liar, dengan ciri berkumpulnya bangunan tempat tinggal orang-orang dengan penghasilan rendah di sempadan sungai, sempadan pantai, dan di atas laut. Permukiman informal berada di area pantai hingga menjorok dari tepi laut di kedalaman 10-50 meter dan sudah ada sejak 20 tahun [4].

Permukiman berkepadatan tinggi yang tidak resmi, kumuh, dan diduduki oleh masyarakat berpenghasilan menengah ke bawah pada kelompok informal misalnya saja buruh lepas atau nelayan merupakan beberapa dari karakteristik sektor informal [5] dan [6]. Ketidakmampuan sektor formal kota dalam menanggapi kebutuhan dasar penduduk merupakan pencetus terbentuknya kelompok pinggiran yang termasuk ke dalam perilaku bertahan hidup pada urbanism [7] dan [8]. Pertumbuhan Kota Bandar Lampung berlangsung dengan sangat cepat dan menjadikan pesisirnya sebagai pusat strategis dalam perdagangan dan jasa. Alhasil kebutuhan masyarakat meningkat dan memungkinkan ruang informal secara konstan tumbuh hingga memenuhi kebutuhan kota mengenai Social Equity "mereka yang kerja di sektor formal namun tinggal di permukiman informal dan sebaliknya" [8]. Masalahnya masyarakat informal yang menduduki kawasan pesisir lebih berisiko baik dengan atau tidak adanya dampak perubahan iklim. Beberapa penelitian menunjukkan hasil bahwa masyarakat yang bertempat di wilayah rentan terdampak bencana justru cenderung memiliki kapasitas adaptif yang besar. Hal ini diprediksi dapat menjadi andalan guna merealisasikan Bandar Lampung dengan ketahanan tinggi di masa depan. Maka dari itu pengkajian yang berkaitan dengan ketahanan kawasan informal terhadap dampak perubahan iklim sangat penting dilakukan guna meningkatkan ketahanan masyarakat sekitar kawasan informal tersebut. Sehingga, tujuan dari studi ini yaitu untuk mengetahui tingkat ketahanan ruang informal atas dampak dari perubahan iklim.

\section{URAIAN PENELITIAN}

Lingkup penelitian berdasarkan lingkup spasial adalah 
kawasan informal yang terletak pada Kelurahan Kota Karang dan Kelurahan Kangkung yaitu di sempadan sungai berdasarkan definisi dari Permen PUPR No. 28 Tahun 2015, sempadan pantai Permen KP No. 21 Tahun 2018, dan di atas lautan. Sedangkan lingkup substansial untuk mengklasifikasikan tingkat ketahanan terhadap dampak perubahan iklim yang didasarkan pada konsep Coastal Community Resilience (2007), Climate Disaster Resilience Index (2009) dan City Resilience Framework (2014) seluruh elemen ketahanan dengan sudut pandang "masyarakat" sebagai sasaran penelitian $[11,12,13]$. Sudut pandang masyarakat dipilih karena pada kawasan informal yang dimaksud adalah tempat tinggal dan pekerjaan serta fokus dalam mewujudkan suatu ketahanan yaitu berfokus pada People Center Development dimana pada berbagai kajian mengenai ketahanan yang banyak berfokus pada masyarakat dan selalu menggunakan aspek sosial dalam menilai suatu ketahanan baik di tingkat masyarakat lokal maupun kota sehingga kita dapat mengklasifikasikan tingkat ketahanan saat ini dan dimensi ketahanan apa saja yang dapat kita intervensi ke depan. Maka dengan melakukan rujukan terhadap konsep ketahanan didapatkan dimensi dan variabel untuk menilai ketahanan pada Tabel 1.

Tabel.1 Dimensi dan Variabel Ketahanan

\begin{tabular}{|c|c|}
\hline Dimensi & Variabel \\
\hline $\begin{array}{c}\text { Kesehatan dan } \\
\text { Kesejahteraan } \\
\text { (KK) }\end{array}$ & $\begin{array}{l}\text { - Memiliki pendapatan, tabungan, investasi, dan } \\
\text { asuransi yang terjamin. } \\
\text { - Tidak memiliki ketergantungan pada pekerjaan } \\
\text { sektor tunggal (punya pekerjaan lain) } \\
\text { - Memiliki jaminan dan akses kesehatan yang } \\
\text { terjangkau } \\
\text { - Memiliki rumah yang aman dan pemenuhan } \\
\text { pangan yang baik } \\
\text { - Memenuhi kebutuhan energi, air minum dan } \\
\text { sanitasi yang layak }\end{array}$ \\
\hline $\begin{array}{c}\text { Infrastruktur dan } \\
\text { Lingkungan/Alam } \\
\text { (ILA) }\end{array}$ & $\begin{array}{l}\text { - Memiliki kesadaran dan pengetahuan risiko } \\
\text { bencana pesisir \& perubahan iklim } \\
\text { - Mendapatkan Pendidikan dan pelatihan } \\
\text { mengenai risiko bencana } \\
\text { - Melakukan penilaian risiko pesisir bersifat } \\
\text { menyeluruh dan rutin dilakukan } \\
\text { - Mendapatkan akses informasi risiko yang mudah } \\
\text { oleh masyarakat dan pemerintah } \\
\text { - Melakukan partisipasi aktif dalam penilaian } \\
\text { risiko } \\
\text { - Memiliki pilihan moda transportasi yang } \\
\text { beragam dan terjangkau } \\
\text { - Memiliki teknologi komunikasi yang andal (ex: } \\
\text { memiliki handphone) } \\
\text { - Memiliki Infrastruktur Bencana yang memadai } \\
\text { (ex: Tanggul, beronjong dll) } \\
\text { - Menyimpan kapasitas cadangan dengan baik } \\
\text { (ex: memanen air hujan dsb) } \\
\text { - Memiliki Layanan dasar yang ramah lingkungan } \\
\text { (ex: Air, transportasi, keamanan, dll.) }\end{array}$ \\
\hline $\begin{array}{l}\text { Guna Lahan dan } \\
\text { Desain Struktur } \\
\text { (GLDS) }\end{array}$ & $\begin{array}{l}\text { - Memasukkan pengurangan risiko ke lokasi dan } \\
\text { desain bangunan.(ex: menghindari sungai dan laut } \\
\text { sebagai sumber bencana dan desain rumah sehat) } \\
\text { - Mendapatkan Program pendidikan, penyuluhan, } \\
\text { dan pelatihan kebijakan lahan dan standar } \\
\text { pembangunan. } \\
\text { - Memiliki bangunan kokoh dan adaptif (ex: }\end{array}$ \\
\hline
\end{tabular}

\begin{tabular}{|c|c|}
\hline \multirow[t]{2}{*}{ Dimensi } & Variabel \\
\hline & $\begin{array}{l}\text { Panggung, meningkatkan lantai bangunan, } \\
\text { terdapat kolong langit, dll). } \\
\text { - Menggunakan bahan dari alam sekitar (ex: } \\
\text { material rumah dengan pohon kelapa) } \\
\text { - Melakukan pemanfaatan lahan sesuai dengan } \\
\text { peraturan/zonasi }\end{array}$ \\
\hline $\begin{array}{l}\text { Strategi dan } \\
\text { Kepemimpinan } \\
\text { (SK) }\end{array}$ & $\begin{array}{l}\text { - Menerapkan proses perencanaan yang bersifat } \\
\text { dua arah (konsultatif) } \\
\text { - Melakukan perencanaan dan proses penetapan } \\
\text { perencanaan yang strategis } \\
\text { - Memiliki hubungan masyarakat dengan } \\
\text { pemerintah yang baik, aktif dan tidak rumit. } \\
\text { - Memiliki legalitas dan sistem regulasi yang } \\
\text { berjalan dengan baik (taat peraturan) } \\
\text { - Memiliki rencana dan kebijakan pembangunan } \\
\text { yang terintegrasi sampai tingkat lokal }\end{array}$ \\
\hline $\begin{array}{c}\text { Manajemen } \\
\text { Sumber daya } \\
\text { pesisir } \\
\text { (MSDP) }\end{array}$ & $\begin{array}{l}\text { - Memiliki Kebijakan dan rencana yang } \\
\text { diimplementasikan serta dimonitor dalam } \\
\text { mengelola sumber daya pesisir } \\
\text { - Melakukan perlindungan pada habitat pesisir } \\
\text { yang sensitif, ekosistem, dan unsur alam } \\
\text { - Memiliki keterlibatan perencanaan dan } \\
\text { menerapkan pengelolaan sumber daya pesisir. } \\
\text { - Menghargai dan berinvestasi dalam pengelolaan } \\
\text { dan konservasi (ex: mangrove). } \\
\text { - Menjaga alam dengan perilaku bersih dan sehat }\end{array}$ \\
\hline $\begin{array}{l}\text { Peringatan dan } \\
\text { Evakuasi } \\
\text { (PE) }\end{array}$ & $\begin{array}{l}\text { - Memiliki sistem peringatan dini yang dapat } \\
\text { berfungsi dengan baik (ex: } E W S \text { ) } \\
\text { - Memiliki sistem peringatan masyarakat dan } \\
\text { evakuasi kebijakan, rencana, prosedur yang } \\
\text { mudah dipahami dan diterapkan } \\
\text { - Memiliki Infrastruktur evakuasi yang terpelihara } \\
\text { dengan baik } \\
\text { - Merespons peringatan bahaya sesuai prosedur } \\
\text { - Mengerti tindakan pertama saat terjadi tanda- } \\
\text { tanda bencana }\end{array}$ \\
\hline $\begin{array}{l}\text { Tanggap darurat } \\
\text { (TD) }\end{array}$ & $\begin{array}{l}\text { - Mampu mengambil peran dan tanggung jawab } \\
\text { saat terjadi bencana } \\
\text { - Mendapatkan kegiatan persiapan (latihan dan } \\
\text { simulasi) secara berkelanjutan } \\
\text { - Memiliki akses terhadap layanan darurat dan } \\
\text { bantuan dasar tersedia. } \\
\text { - Memiliki organisasi dan sukarelawan serta } \\
\text { keuangan untuk mendukung kegiatan tanggap } \\
\text { darurat (eksternal) } \\
\text { - Memiliki organisasi masyarakat atau lainnya } \\
\text { yang biasa menangani dengan cepat }\end{array}$ \\
\hline $\begin{array}{l}\text { Pemulihan } \\
\text { Bencana } \\
\text { (PB) }\end{array}$ & $\begin{array}{l}\text { Memiliki rencana pemulihan berdasarkan } \\
\text { kondisi masyarakat serta cepat dilakukan } \\
\text { - Melakukan pemulihan bencana dengan } \\
\text { dimonitor, dievaluasi, dan diperbaiki. } \\
\text { - Mekanisme koordinasi dari pusat sampai lokal } \\
\text { berjalan baik } \\
\text { - Memiliki sumber-sumber teknis dan keuangan } \\
\text { yang tersedia dalam pemulihan }\end{array}$ \\
\hline
\end{tabular}

Sumber : [11,11,13]

\section{METODOLOGI}

\section{A. Metode Pengumpulan Data}

Data primer adalah dengan teknik questionnaire-based interview. Responden penelitian ini ditentukan dengan perhitungan banyak sampel minimal dengan rumus lemeshow sebagai berikut.

Dikarenakan jumlah populasi yang tidak diketahui secara 
pasti, maka penarikan sampel menggunakan rumus lemeshow seperti pada penjabaran berikut:

$$
n=\frac{\left[Z^{2} \cdot P(1-P)\right]}{E^{2}}
$$

$n=$ jumlah sampel minimal yang diperlukan

$Z=$ skor $z$ pada tingkat kepercayaan

$P=$ variasi populasi (dalam penelitian ini karakteristik populasi diasumsikan beragam, maksimal $=0.5$ )

$E=$ alpha atau sampling error yang dikehendaki

Berdasarkan hasil yang didapatkan dari perhitungan menggunakan rumus di atas, $\mathrm{n}$ yang didapatkan adalah 96,04 dan ditambahkan $10 \%$ error sehingga $10 \%$ dari total minimal sampling yang ditambahkan berupa 9 sampel. Oleh sebab itu, pada studi ini membutuhkan data 105 orang [14].

\section{B. Metode Analisis Data}

Pendekatan kuantitatif yang terdiri dari metode skoring dan pembobotan untuk mengidentifikasi persentase ketahanan dimensi dan variabel ketahanan. Kemudian, analisis statistik inferensial dilakukan persentase ketahanan berdasarkan kriteria yang telah dibuat sebagai ketentuan tingkat ketahanan dimensi [9]. Klasifikasi tersebut dapat dilihat pada Tabel 2.

Tabel 2. Pembobotan Nilai Masing-masing Variabel

\begin{tabular}{|l|l|l|}
\hline \hline Nilai & \multicolumn{1}{|c|}{ Keterangan } & $\begin{array}{l}\text { Persentase } \\
\text { Ketahanan }\end{array}$ \\
\hline 5 & Memuaskan & $81-100 \%$ \\
4 & Sangat Baik & $61-80 \%$ \\
3 & Baik & $41-60 \%$ \\
2 & Cukup & $21-40 \%$ \\
& Kurang & $1-20 \%$ \\
0 & Kondisi Tidak Ada/Tidak Tahu & \\
\hline \hline
\end{tabular}

Sumber : [11]

Selanjutnya, dilakukan akumulasi untuk menentukan klasifikasi tingkat ketahanan kawasan yang terbagi menjadi tiga kelas[13]. Klasifikasi tersebut dapat dilihat pada Tabel 3.

Tabel 3. Klasifikasi Tingkat Ketahanan

\begin{tabular}{l|l|l}
\hline \hline \multicolumn{3}{c}{ Klasifikasi Tingkat Ketahanan } \\
\hline Merah & High Resilience & $61 \%-100 \%$ \\
Kuning & Intermediate & $41-60 \%$ \\
Hijau & Low Resilience & $0-40 \%$ \\
\hline \hline
\end{tabular}

Setelah itu, dilakukan analisis faktor dan kuadran utama untuk menentukan dimensi ketahanan apa saja yang termasuk dimensi prioritas berdasarkan pembagian kuadran dan perlu dilakukan intervensi sebagai bentuk rekomendasi. Pembagian diagram pada Gambar 1.

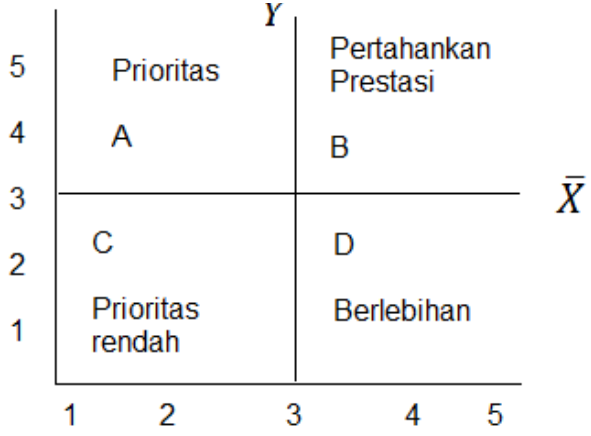

Gambar 1. Pembagian diagram kuadran utama.

\section{DISKUSI DAN PEMBAHASAN}

Ketahanan iklim kota mendapatkan perhatian khusus di wilayah pesisir Kota Bandar Lampung, salah satunya di ruang informal yang hadir di Kelurahan Kota Karang. Ketahanan iklim kota ini dilakukan untuk melihat kondisi saat ini dengan cara melakukan penilaian terhadap beberapa dimensi ketahanan yang terbagi menjadi 45 variabel yang diungkapkan dalam sebuah pernyataan sehingga didapatkan tingkat ketahanan yang dapat dijadikan acuan dalam pengembangan ke depan dalam meningkatkan ketahanan kawasan informal di pesisir Kota Bandar Lampung. Rata-rata nilai dimensi ketahanan yang didapatkan di kawasan informal yang berada di Kelurahan Kota Karang berada di rentang tiga sampai empat dengan indeks sedang. Meskipun demikian, nilai ini masih menunjukkan belum maksimalnya upaya di dalam melakukan manajemen bencana. Penilaian terhadap sembilan dimensi dan 45 variabel yang digunakan digambarkan di spiderchart yang dapat dilihat di Gambar 2.

\section{TINGKAT KETAHANAN KAWASAN INFORMAL DI KEL. KOTA KARANG}

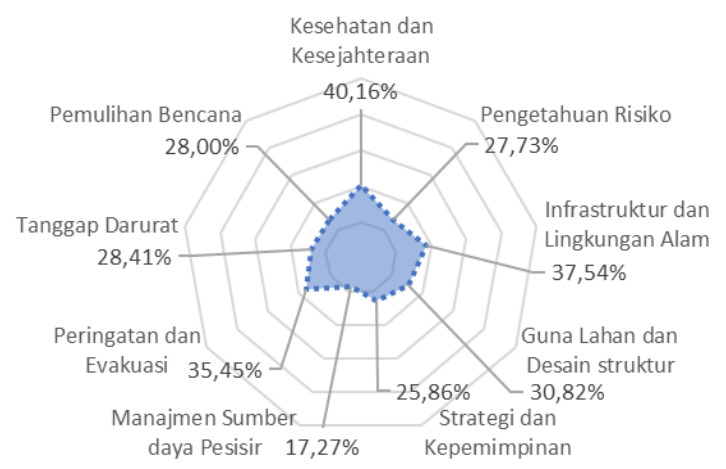

Gambar 2. Tingkat ketahanan kota pada kawasan informal di sebagian Kelurahan Kota Karang.

Berdasarkan spiderchart di atas, dimensi ketahanan ruang informal pada Kelurahan Kota Karang memiliki tingkat ketahanan rendah $(0-40 \%)$ dengan persentase ketahanan $30,14 \%$. Persentase ketahanan terendah pada dimensi manajemen sumber daya pesisir yaitu $17,27 \%$ dengan keterangan ketahanan kurang (0-20\%). Sedangkan persentase ketahanan tertinggi dimensi kesehatan dan kesejahteraan 
40,16\% dengan keterangan ketahanan cukup. Seperti yang sebelumnya sudah diulas di atas, bahwa pengelolaan sumber daya pesisir sangat buruk. Kurangnya kesadaran menjaga lingkungan sangat terlihat jelas pada area pemukiman yang bertempatan di sekitar sempadan sungai dan di atas laut. Tumpukan sampah dan perubahan fungsi kawasan konservasi mangrove terus dilakukan. Tercatat bahwa terjadi pengurangan yang sangat signifikan dari tahun 1993 sampai 2016 sekitar 53,3 ha hutan mangrove yang ada di Kelurahan Kota Karang teralih fungsikan dan bersisa hanya 6 ha 90,14\% teralih fungsikan dari kondisi awal [14]. Kondisi permukiman yang terus memadat kebutuhan akan lahan yang terus meningkat membuat hutan-hutan mangrove saat ini mengalami perubahan fungsi, kondisi tersebut digambarkan secara jelas pada Gambar 3.

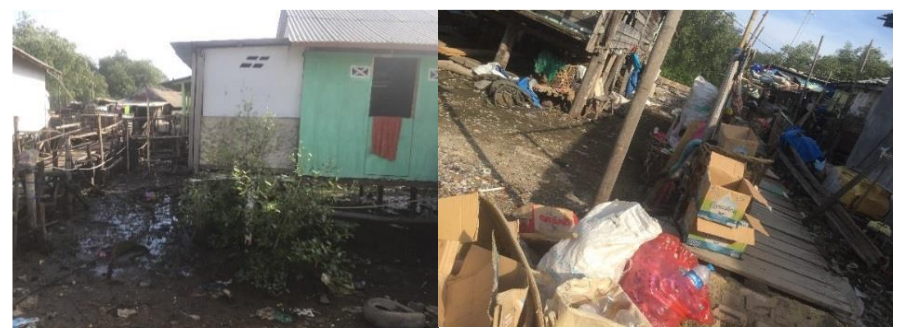

Gambar 3. Rumah panggung di kawasan mangrove.

Hutan mangrove yang ada di Kelurahan Kota Karang sampai saat ini terus mengalami penurunan luasan akibat pembangunan yang terus terjadi di sana. Penurunan luasan tersebut dapat mempengaruhi tingkat ketahanan kawasan informal, dalam hal ini kawasan informal tersebut dijelaskan berdasarkan tiga lokasi utama studi yaitu permukiman di sempadan pantai, sempadan sungai, serta di atas lautan. Sebagaimana yang telah dijelaskan, pada tingkat ketahanan dimensi manajemen sumber daya pesisir perlu ada perhatian khusus bagi masyarakat untuk aktif mengelola sumber daya pesisir sesuai dengan karakteristik lokasi. Berikut tingkat ketahanan kawasan informal di sempadan sungai, pantai, dan di atas laut pada Kelurahan Kota Karang pada Gambar 4.

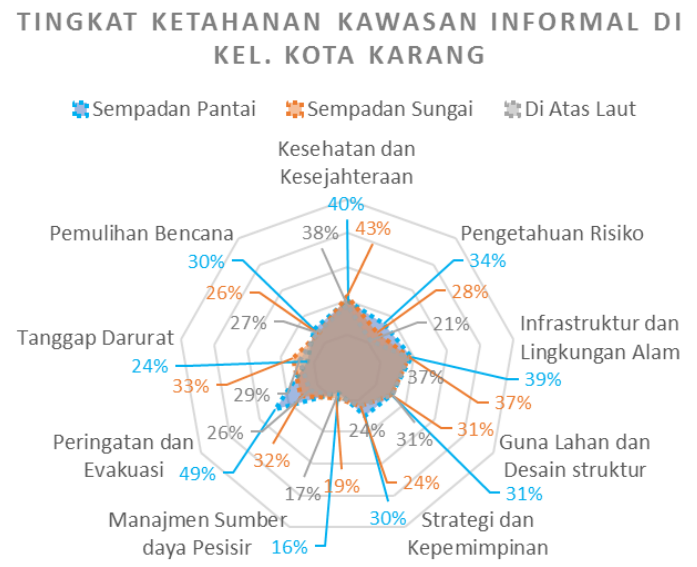

Gambar 4. Spiderchart tingkat ketahanan kawasan informal di tiga lokasi studi di Kelurahan Kota Karang.
Persentase ketahanan pada sempadan sungai 32,43\% (rendah) dengan dimensi ketahanan tertinggi peringatan dini dan evakuasi sebesar 49\% (baik) dan persentase ketahanan terendah adalah manajemen sumber daya pesisir yaitu $16 \%$ (rendah). Sedangkan, pada sempadan pantai memiliki tingkat ketahanan rendah $30,27 \%$. Dimensi ketahanan infrastruktur dan lingkungan alam memiliki persentase ketahanan paling tinggi yaitu $43 \%$. Sedangkan, di atas laut memiliki tingkat ketahanan rendah $(27.71 \%)$. Dimensi terendah dan tertingginya sama dengan kawasan di sempadan pantai.

Pada kawasan informal yang ada di Kelurahan Kota Karang, lokasi penelitian yang memiliki hasil tingkat ketahanan dari yang paling rendah secara berurutan yaitu di atas laut, sempadan pantai, dan sempadan sungai. Area di atas laut dan sempadan pantai menjadi paling rendah karena memang sampai saat ini kelurahan yang memiliki kawasan konservasi mangrove adalah Kelurahan Kota Karang, meskipun kondisi saat ini sangat mengkhawatirkan. Upaya peningkatan ketahanan yang mungkin diterapkan ke depannya adalah melalui peningkatan peran dan fungsi masyarakat dalam mengelola sumber daya pesisir. Setiap masyarakat berkewajiban berperan aktif dalam pengambilan keputusan dan pelaksanaan perlindungan dan pengelolaan lingkungan hidup. Setiap masyarakat memiliki kesempatan dalam perencanaan, pelaksanaan, dan pengawasan terhadap pengelolaan wilayah pesisir dan pulau-pulau kecil [17] dan [18].

Sehingga, pengelolaan sumber daya pesisir berbasis masyarakat cukup tepat untuk dilakukan, mulai dari pemetaan pembagian zonasi, pembuatan rencana pengelolaan yang melibatkan masyarakat, menjaga alam dengan tidak menggunakan alat atau bahan yang dapat membahayakan, serta berperilaku bersih dan sehat dapat membiasakan masyarakat mencintai lingkungannya sendiri sehingga kondisi alam akan tetap lestari. Mengaktifkan kembali program bank sampah, menambahkan titik lokasi, dan membuat pengolahan ikan dengan sistem yang ramah lingkungan dengan tidak langsung membuang limbahnya ke laut, melainkan bekerja sama dengan dinas terkait dalam pengelolaan persampahan di pesisir kota.

Begitu juga dengan kawasan informal yang ada di Kelurahan Kangkung, perhatian mengenai tingkat ketahanan ini perlu ditingkatkan. Pasalnya, berdasarkan penilaian yang dilakukan, hanya sekitar dua sampai tiga yang berindeks rendah. Kawasan informal yang ada di Kelurahan Kangkung ini memang lebih memprihatinkan. Berdasarkan kondisi di lapangan, memang karakteristik wilayah di kelurahan ini sangat buruk. Hampir 80 persen wilayah memang merupakan area yang dulunya laut sekitar 100-200 meter dari lautan telah dilakukan reklamasi dengan cara menimbun bahan bangunan yang sudah tidak terpakai dan sampah-sampah rumah tangga serta hasil pengerukan dari bukit-bukit sekitar, memang sempat ada proyek reklamasi oleh PT. BBS yang terhenti sehingga kondisi ilegal ini yang berbenturan dengan aturan sehingga program atau bantuan sulit untuk diberikan. Berdasarkan penilaian terhadap sembilan dimensi dan 45 indikator yang digunakan dapat digambarkan spiderchart pada 
Gambar 5 .

TINGKAT KETAHANAN KAWASAN INFORMAL DI KEL. KANGKUNG

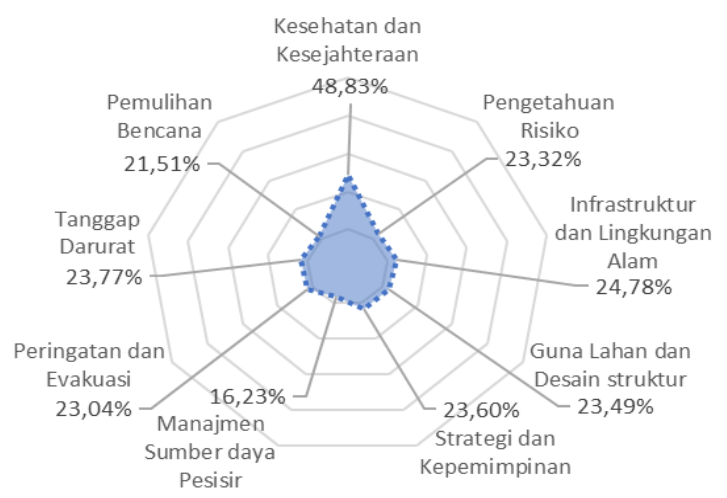

Gambar 5. Spiderchart tingkat ketahanan kawasan di Kelurahan Kangkung.

Tingkat ketahanan kawasan informal di Kelurahan Kangkung, menunjukkan persentase ketahanan 25,40\% (rendah). Dimensi hampir seluruhnya memiliki ketahanan cukup (21-40\%) sehingga intervensi harus dilakukan agar penghidupan dan segala sistem yang mengatur dapat meningkatkan ketahanan. Nilai paling rendah manajemen sumber daya pesisir sebesar 16,23\% (rendah).

Regulasi dan legalitas yang tidak ditaati juga kurangnya koordinasi pemerintah setempat dengan masyarakat membuat kondisi di kawasan tersebut terus memprihatinkan. Erat kaitannya dalam keamanan dalam bertempat tinggal, mata pencaharian yang berkelanjutan. Ketika kerusakan lingkungan yang terjadi akibat kurangnya kesadaran dan penyadaran yang dilakukan sehingga pelanggaran terus dilakukan yang justru risiko tersebut akan semakin membesar ketergantungan masyarakat terhadap kondisi alam yaitu sumber penghidupan mereka sendiri karena sebagian besar merupakan buruh nelayan yang tidak punya keahlian lain serta kemungkinan terkena dampak dari bahaya alam yang ditimbulkan juga semakin besar yang pada akhirnya berdampak pada kecepatan pemulihan pasca bencana jika sewaktu-waktu terjadi. Kerusakan lingkungan akibat kesadaran masyarakat yang masih kurang pada Gambar 6.

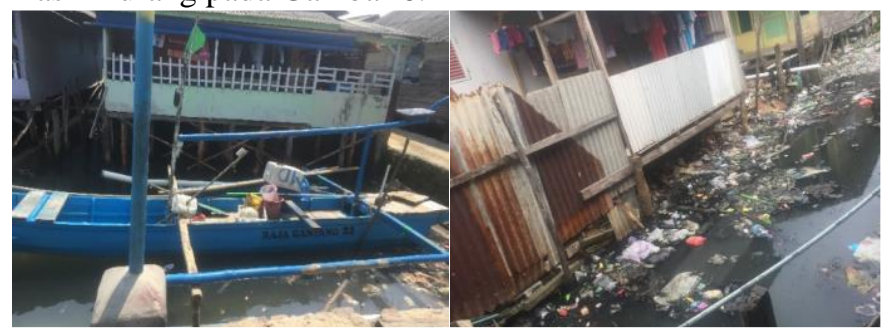

Gambar 6. Rumah di atas laut dan tumpukan sampah.

Fenomena rumah di atas laut dengan tumpukan sampah yang ada di sungai-sungai dan kolong-kolong rumah panggung menjadi pemandangan yang tidak asing di kawasan informal yang ada di Kelurahan Kangkung. Kondisi ini dapat memengaruhi ekosistem alam yang ada di sana, sekaligus meningkatkan kerentanan dari ancaman bencana pesisir. Sampai saat ini, kebiasaan masyarakat tersebut menjadi permasalahan yang belum terselesaikan. Pasalnya, banyak masyarakat mengeluhkan bahwa sampah yang ada di wilayahnya bukan hanya dari masyarakat sekitar saja melainkan dari masyarakat di hulu sungai, sehingga kegeraman dengan membersihkan sungai dirasa tidak ada akhirnya. Selain itu, pengelolaan sampah kota tidak terlalu serius dalam menangani sampah pesisir yang kemungkinan ada kesulitan bagi petugas untuk masuk membersihkan karena akses masuk yang sangat sempit. Berikut tingkat ketahanan kawasan informal di sempadan sungai, pantai, dan di atas laut di Kelurahan Kangkung pada Gambar 7.

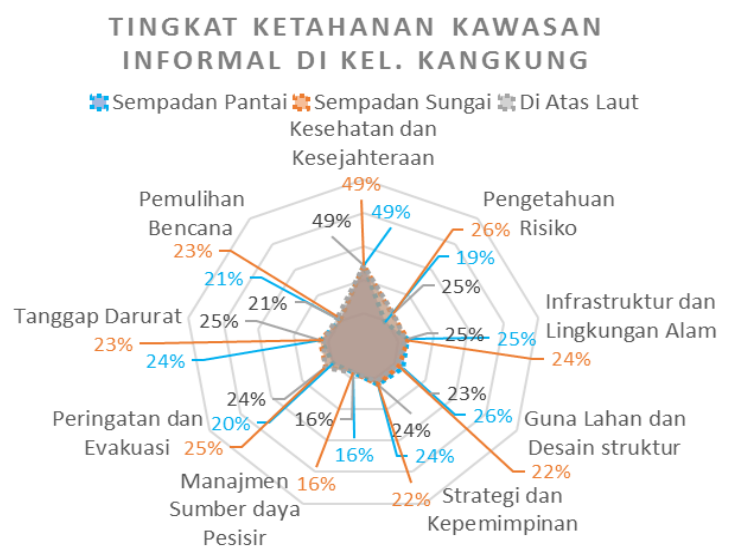

Gambar 7. Spiderchart tingkat ketahanan kawasan informal di sempadan sungai Kelurahan Kangkung.

Persentase ketahanan sempadan pantai memiliki persentase ketahanan 25,50\% yaitu tingkat ketahanan rendah (0-40\%). Sedangkan dimensi kesehatan dan kesejahteraan memiliki persentase ketahanan $49 \%$ dengan keterangan ketahanan baik (41-60\%) sedangkan dimensi manajemen sumber daya pesisir memiliki persentase ketahanan $16 \%$ dengan keterangan ketahanan kurang $(0-20 \%)$. Sedangkan pada sempadan sungai memiliki tingkat ketahanan sedang dengan persentase ketahanan 25,78\% tingkat ketahanan rendah (0-40\%). Sedangkan dimensi ketahanan yang tertinggi dan terendah sama seperti sempadan pantai. Terakhir, kawasan di atas laut juga memiliki tingkat ketahanan rendah $(0-40 \%)$ dengan persentase ketahanan $24,91 \%$.

Kawasan informal di Kelurahan Kangkung, berdasarkan pembagian daerah studi, secara berturut-turut memiliki tingkat ketahanan yang paling rendah yaitu di atas laut, sempadan pantai, dan sempadan sungai. Hal tersebut terjadi karena berdasarkan urutannya tingginya skor variabel ketahanan adalah yang pertama Infrastruktur dan lingkungan alam, berdasarkan cakupan pelayanan dasar dan penyesuaian material penyusun bangunan yang adaptif memiliki nilai yang tinggi. Akan tetapi, perilaku hidup bersih dan sehat menyumbang skor paling rendah. Sedangkan, pada dimensi terendah manajemen sumber daya pesisir variabel yang membuat ketahanan menurun adalah kebiasaan masyarakat yang sengaja membuang sampah ke laut dan terus melakukan reklamasi serta pembangunan di atas laut sehingga penataan ruang laut menjadi berantakan, penyediaan pelayanan dasar seperti drainase, jalan, dan utilitas menjadi kurang baik. 
Akhirnya, banyak kejadian bencana menjadi lebih buruk mereka hadapi.

Upaya yang dapat dilakukan dalam mengatasi permasalahan utama yang ada di area sempadan pantai dan di atas laut adalah dengan melibatkan masyarakat dalam setiap pembangunan yang ada. Upaya ini dilakukan untuk membantu masyarakat dalam memahami kondisi lingkungannya saat ini dan juga berupaya untuk menjadikan masyarakat stakeholder utama yang dapat menjaga, merawat, dan memfungsikan berbagai fasilitas yang diberikan oleh pemerintah sehingga penggunaannya dapat berkelanjutan. Penataan kembali tata ruang pesisir menjadi pilihan yang harus diambil, dengan mempertegas batas pantai/sempadan dan perizinan sekaligus kriteria yang harus dipenuhi bagi masyarakat yang sudah terlanjur bertempat tinggal di kawasan tersebut agar diberikan opsi untuk berpindah ke tempat yang lebih layak di daerah darat atau mengikuti standard operating procedure (SOP) yang harus segera dibuat.

Sehingga, mereka yang tetap tinggal di sana dapat beradaptasi dan mendapatkan perlindungan atau pencegahan dari berbagai mitigasi yang dilakukan. Karena memang tumbuh permukiman informal itu tanpa rencana dan mereka tidak disalahkan karena peraturan yang baru mengakomodasi pun baru beberapa tahun kebelakangan ini sehingga untuk tindak tegas pelarangan baru bisa dilakukan. Saat ini, yang bisa dilakukan adalah memberikan pemahaman akan kondisi lingkungannya seperti bencana yang mereka hadapi dan dampak perubahan iklim yang dapat memperburuk hal tersebut. Sehingga, upaya adaptasi dan mitigasi berbasis masyarakat dapat dilakukan berdasarkan karakteristik masyarakat yang ada di sana. Tugas seluruh pemangku kepentingan di luar masyarakat itu sendiri untuk memberikan pemahaman tersebut.

Secara keseluruhan, tingkat ketahanan kawasan informal memiliki persentase ketahanan 27,82\% dengan keterangan ketahanan rendah (0-40\%). Dimensi yang memiliki ketahanan baik (41-60\%) yaitu dimensi kesehatan dan kesejahteraan dengan nilai 44,56\%. Sedangkan, dimensi manajemen sumber daya pesisir memiliki persentase ketahanan rendah (0-20\%) yaitu $16,80 \%$ dan tujuh dimensi lain memiliki ketahanan cukup (21-40\%). Tingkat ketahanan tersebut dapat dilihat pada spiderchart yang ditunjukkan pada Gambar 8 .

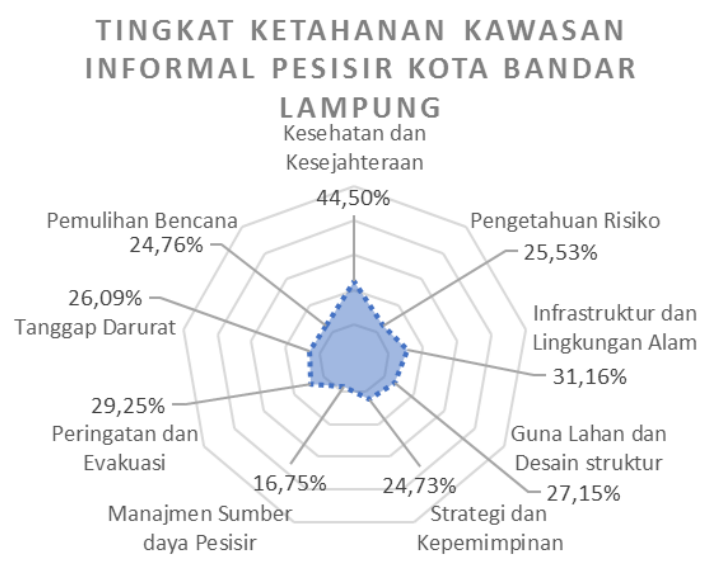

Gambar 8. Spiderchart tingkat ketahanan kawasan informal pesisir Kota Bandar Lampung.

Hasil tersebut menunjukkan bahwa dimensi ketahanan masih bisa dioptimalkan dan berdasarkan lokasi. Beberapa kegiatan adaptasi dan mitigasi yang dilakukan dapat mencerminkan bahwa masyarakat tersebut mampu memproses segala sumber daya yang dimiliki dengan kondisi tempat tinggal mereka untuk tetap bisa bertahan menjalankan kehidupan dengan normal di sana. Dimensi kesehatan dan kesejahteraan tinggi karena program bantuan pemerintah yang didapatkan oleh seluruh masyarakat, tidak kecuali mereka yang bertempat tinggal di lahan ilegal. Masalahnya, hal ini pula yang membuat dimensi lain menjadi rentan karena pelegalan dan bantuan program yang diberikan justru membuat masyarakat tidak sadar bahwa mereka bertempat tinggal di kawasan yang berisiko tinggi dengan lingkungan yang tidak mendukung kehidupan yang layak dan dapat merusak ekosistem yang ada di sana. Sumber daya yang melimpah bisa saja habis sewaktu-waktu dan guncangan seperti banjir bandang, rob, tsunami, atau badai tidak menyisakan apa pun. Untuk itu, perlu adanya intervensi yang sesuai dengan kebutuhan dalam meningkatkan ketahanan kawasan tersebut sehingga ketika ada kenaikan pada dimensi ketahanan bisa memengaruhi kehidupan yang lebih baik, tidak sebaliknya seperti yang terjadi saat ini. Hal itu akan coba dijawab di pembahasan selanjutnya yaitu dimensi prioritas ketahanan yang akan dijelaskan pada sub bab berikutnya.

Selanjutnya juga dilakukan analisis kuadran dengan metode important-performance analysis untuk menentukan variabelvariabel yang perlu dilakukan intervensi untuk meningkatkan resiliensi kawasan informal pesisir Kota Bandar Lampung selanjutnya pada Gambar 9.

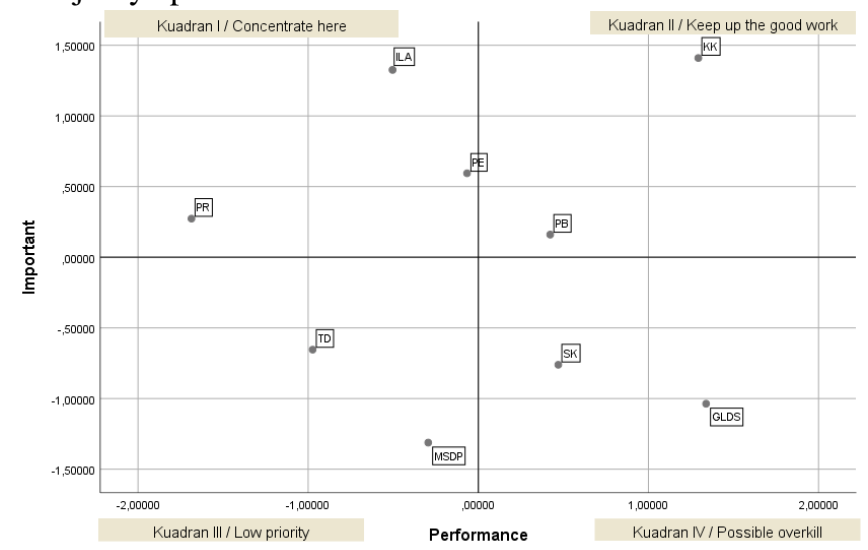

Gambar 9. Plotting dimensi pada kuadran hasil analisis kuadran utama.

Berdasarkan hasil analisis kuadran utama di atas, dapat dilihat bahwa pada plotting kuadran di atas dapat kita lihat dan bagi berdasarkan ketentuan masing-masing kuadran yang dapat diartikan sebagai berikut:

a. Kuadran I : Infrastruktur dan Lingkungan Alam (ILA), Pengetahuan Risiko (PR), dan Peringatan dini dan Evakuasi (PE) memiliki pengaruh cukup signifikan namun dibutuhkan intervensi meningkatkan ketahanan agar dijadikan prioritas utama yang dikembangkan. 
b. Kuadran II : Kesehatan dan Kesejahteraan dan Pemulihan Bencana perlu dipertahankan karena memberi pengaruh cukup signifikan dengan nilai performa yang baik.

c. Kuadran III : Kuadran III terdiri dari dimensi Tanggap darurat (TD) dan Manajemen Sumber Daya Pesisir (MSDP) yang bermakna variabel ini tidak terlalu mempengaruhi secara cukup signifikan dengan catatan diperlukan intervensi atau peningkatan performa untuk peningkatan ketahanan.

d. Kuadran IV : Strategi dan Kepemimpinan (SK) dan Guna Lahan dan Desain Struktur (GLDS) memiliki arti bahwa pengaruhnya cukup signifikan. Selain itu, nilai performanya juga sudah cukup baik, sehingga tidak terlalu diperlukannya intervensi.

Maka, berdasarkan hasil plotting kuadran dan keterangan masing-masing kuadran, dimensi-dimensi yang lebih butuh dilakukan intervensi adalah dimensi-dimensi pada kuadran I dan III, sedangkan dimensi yang berada pada kuadran II dan IV tidak terlalu urgent untuk diintervensi termasuk hasil dari skalogram Pemulihan Bencana/PB masuk kuadran II yang tidak diprioritaskan. Selain itu, juga dilakukan usulan intervensi yang sebaiknya dilakukan pada dimensi prioritas berdasarkan hasil analisis plotting kuadran tersebut.

\section{KESIMPULAN/RINGKASAN}

Terdapat delapan dimensi ketahanan yang tergolong rendah $(0-40 \%)$ dan satu dimensi ketahanan tergolong sedang (41$60 \%$ ), dengan tingkat ketahanan dari yang paling rendah berdasarkan pembagian tiga daerah studi kawasan informal di Kelurahan Kota Karang berdasarkan urutannya yaitu kawasan informal di atas laut, sempadan pantai, dan sempadan sungai. Kelurahan Kangkung berturut-turut mulai yang terendah yaitu atas laut, sempadan pantai, dan sempadan sungai. Secara keseluruhan, tingkat ketahanan kawasan informal berada di tingkat ketahanan rendah (0-40\%) yaitu $27,77 \%$.

Permasalahan perkotaan akibat jumlah penduduk disertai kebutuhan yang terus meningkat, terutama lahan, menyebabkan sektor-sektor informal bermunculan sehingga pesisir kota menjadi salah satu kawasan yang menjadi alternatif pilihan masyarakat Kota Bandar Lampung untuk bertempat tinggal karena merupakan wilayah perkotaan atau pusat kota yang justru meningkatkan risiko karena legalitas yang dilanggar dan perilaku yang dapat merusak lingkungan. Kepadatan bangunan dan ekosistem pesisir yang terus mengalami degradasi menjadi penyebab fungsinya tidak lagi mampu mempertahankan atau meminimalkan terbenamnya pesisir akibat muka air laut yang naik dan curah hujan tinggi yang merupakan dampak dari perubahan iklim. Risiko tersebut telah dirasakan seperti meningkat erosi pantai, sedimentasi yang cepat, dan banjir wilayah pesisir lebih buruk.

Berkaitan dengan faktor-faktor yang menyebabkan ketahanan dan peningkatan kerentanan di kawasan informal pesisir Kota Bandar Lampung, perlu dilakukan peningkatan terhadap dimensi ketahanan yang dapat diprioritaskan penanganannya untuk dilakukan intervensi. Berdasarkan hasil analisis kuadran utama, dimensi dan variabel tersebut berada di kuadran satu dan tiga yaitu Infrastruktur dan Lingkungan
Alam (infrastruktur bencana), Pengetahuan risiko (pelatihan dan sosialisasi), dan Peringatan Dini dan Evakuasi (rencana dan prosedur evakuasi) berada di kuadran satu. Sedangkan, Tanggap Darurat (simulasi) dan Manajemen Sumber Daya Pesisir (pengelolaan sumber daya, konservasi mangrove, dan perilaku hidup bersih dan sehat) berada di kuadran tiga. Selanjutnya, dimensi ketahanan ini dapat diharapkan untuk dilakukan prioritaskan penangananmya dalam implementasi kehidupan sehari-hari yang dapat mengatasi berbagai ancaman atau risiko dari dampak perubahan iklim.

\section{UCAPAN TERIMA KASIH}

Terima kasih kepada Program Studi Perencanaan Wilayah dan Kota Institut Teknologi Sumatera dan Fakultas Pertanian Universitas Lampung dalam mendukung penyelesaian penelitian ini. Juga, seluruh narasumber, baik warga Kelurahan Kangkung dan Kelurahan Kota Karang maupun Pemerintah dan NGO, yang telah meluangkan waktunya memberikan masukan pada penelitian ini. Semoga perspektif yang coba penulis bawa dengan memperlihatkan kawasan informal dengan masyarakat yang bertempat tinggal dan hidup di tempat ilegal memperlihatkan bahwa kita bisa belajar dari mereka untuk bisa tetap bertahan dari berbagai ancaman dan ini merupakan embrio awal dari ketahanan itu sendiri.

\section{DAFTAR PUSTAKA}

[1] Fankhauser, S., McDermott, T., dan Costa, H. (2016). Climate-resilient cities. In The Economics of Climate-Resilient Development. https://doi.org/10.4337/9781785360312.00018 Tanggal akses : 10 Desember 2019.

[2] Direktorat Pengembangan Kawasan Permukiman. (2016). Permukiman Kumuh dan Upaya Penanganannya. Diakses pada tanggal 01 Januari 2020:http://ciptakarya.pu.go.id/bangkim/nusp2/index.php?/berita/detail/ permukiman-kumuh-dan-upaya penanganannya.

[3] Mukhlis, M., Putri, D. M., dan Purnawaty, D. (2011). Strategi Ketahanan Kota Bandar Lampung Terhadap Perubahan Iklim 20112030. Bandar Lampung: Asian Cities Climate Change Resilience Network (ACCCRN).

[4] Taylor, J. (2010). Community Based Vulnerability Assesment Semarang and Bandar Lampung, Indonesia. Semarang dan Bandar Lampung: ACCCRN dan Mercy Corps.

[5] Indrawan, T. A. (2005). Hubungan Sektor Informal dengan Kesempatan Kerja dan Kesempatan Menyekolahkan Anak (Studi Sektor Informal di Pinggir Jalan Ki Hajar Dewantoro Belakang Kampus Kentingan Universitas Sebelas Maret Surakarta). Surakarta: Univeristas Sebelas Maret.

[6] Hart, K. (1973). Informal income opportunities and urban employment in ghana. The Journal of Modern African Studies, hal 61-89. https://doi.org/10.1017/S0022278X00008089 Tanggal akses : 11 Desember 2019.

[7] Roy, A. (2005). Urban informality: Toward an epistemology of planning. Journal of the American Planning Association, hal 147-158. https://doi.org/10.1080/01944360508976689. Tanggal akses : 09 Desember 2019.

[8] Soto, H. D. (1941). The Mystery of Capital. New York: Basic Books, A Member of the Perseus Books Group.

[9] U.S. Indian Ocean Tsunami Warning System Program. (2007). Community? A Guide for Evaluating Coastal Community Resilience to Tsunamis and Other Coastal. Bangkok: U.S. IOTWS.

[10] SHAW, R. (2009). Climate Disaster Resilience. Kyoto: International Environment and Disaster Management (IEDM) Laboratory, Graduate School of Global Environmental Studies.

[11] Bhoite, S., Kieran , B., Cook, S., Diaz, S., Evans, V., Fernandez, A., Tonking, F. (2014). City Resilience Framework. London WIT 4BQ: ARUP. 
[12] Lemeshow, S., W. Hosmer Jr, D., Klar, J., dan K.Lwanga, S. (1990). Adequacy of Sample Size in Health Studies. Chichester: Jhon Willey \& Sons Ltd.

[13] Farida, M. A., dan Rahayu, H. P. (2017). Kajian Tingkat Resiliensi Kawasan Pariwisata Sanur terhadap Tsunami ditinjau dari Aspek Atraksi, Aktivitas, dan Amenitas. Perencanaan Wilayah dan Kota.

[14] A.A Kurnia dan A Hasana. (2016). Analisis Spasial Dan Temporal Perubahan Karakteristik Ekosistem Mangrove di Wailayah Pesisir Kota Bandar Lampung. Journal of Environment and Sustainable Development. Vol 1. 